\title{
Cognitive Contemporary Behaviour Management Outline
}

\author{
Birti Singh ${ }^{1}$, Seema Deshmukh ${ }^{2}$ \\ ${ }^{1,2}$ Department of Paediatric \& Preventive Dentistry, JSS Academy of \\ Higher Education \& Research, Mysore, Karnataka, India.
}

\section{ABSTRACT}

\section{BACKGROUND}

Paediatric dentists are expected to recognize and effectively treat childhood dental diseases which can be cumbersome owing to the child's inert anxiety and fear. Behaviour management techniques facilitate communication and establish social and behavioural guidelines for the dental environment. On what basis do paediatric dentists decide the appropriate management techniques for a child? This requires an understanding of children's expected behaviour at different stages of intellectual development. Jean Piaget theorized cognitive development through four stages. According to him, children's knowledge about reality is acquired by touching and observing, balanced by an interplay between assimilation and accommodation. The objective of the study was to prepare an outline integrating contemporary behaviour management techniques with Piaget's cognitive development stages for a child to be able to provide them with a positive dental experience.

\section{METHODS}

A thorough literature search was done utilising different search engines (PubMed, Scopus, MedLine and google scholar) using different key words from the MeSH terminologies database. Comparative clinical trials and randomized clinical trials were included in the study and the recommendations were tabulated.

\section{RESULTS}

After performing a literature review, relevant articles were identified from various search engines. Piaget's theory was reviewed as it views cognitive and intellectual activities as adaptive and helpful for the child in coping, organizing and reorganizing their thoughts and actions.

\section{CONCLUSIONS}

A systematic outline was prepared with the goal to develop a guideline fitting the objectives of this paper.

\section{CLINICAL SIGNIFICANCE}

This outline will enable the paediatric dentist to decide the appropriate behaviour management technique to provide a positive dental experience for a child in accordance with their expected cognitive and intuitive stage of development.

\section{KEY WORDS}

Cognitive Development Theory, Behaviour Management, Jean Piaget, Child Psychology
Corresponding Author: Dr. Seema Deshmukh, Associate Professor, Dept of Paediatric \& Preventive Dentistry, JSS Dental College \& Hospital, Mysore, Karnataka, India.

E-mail:dr.seemadeshmukh@jssuni.edu.in

DOI: $10.14260 /$ jemds $/ 2021 / 719$

How to Cite This Article:

Singh B, Deshmukh S. Cognitive contemporary behaviour management outline. J Evolution Med Dent Sci 2021; 10(40):3548-3553 DOI: 10.14260/jemds/2021/719

Submission 06-08-2021,

Peer Review 20-09-2021, Acceptance 27-09-2021, Published 04-10-2021.

Copyright (C) 2021 Birti Singh et al. This is an open access article distributed under Creative Commons Attribution License [Attribution 4.0 International (CC BY 4.0)] 


\section{BACKGROUND}

Paediatric dentists are expected to effectively recognize and treat children having dental diseases with their professional education and expertise. Providing safe and effective treatment to children requires a thorough knowledge of dental diseases as well as an understanding of the behaviour displayed by children of all ages. This can be achieved by behaviour guidance, a process implied by professionals to identify the appropriateness of behaviour in the dental setting and further shape it such that quality dental care can be provided. ${ }^{1}$ A child's age and development of cognition influences greatly their responses to behaviour guidance and management. ${ }^{2}$ Hence an age-wise guided understanding of a child's behaviour influenced by their cognitive development is needed to be adapted to the behaviour management techniques.

Cognitive development is the construction of thought processes, including remembering, problem-solving, and decision making from childhood through adolescence to adulthood. Jean Piaget, the famous Swiss Genetic Epistemologist pioneered in this field and theorized cognitive development in children through four stages: the sensorimotor period (beginning at birth until two years), preoperational thought period (two to seven years), concrete operational thought period (seven to twelve years) and formal operational thought period (twelve years and above). He studied a child's view of their surrounding world, and their acquisition of the systems of knowledge including logic, measurement, concept formation, morality, development of language, and theory of physical reality. ${ }^{3}$

Piaget's theory has been reviewed in this paper as he is considered to be the most influential theorist in the study of cognitive development. ${ }^{4}$ His theory views cognitive and intellectual activities as adaptive and as helping the child in coping, organizing and reorganizing their thoughts and actions. $^{3}$ According to him, intellectual growth for an individual progresses through a sequence of maturational changes; ${ }^{4,5}$ and intelligence is the ability to adapt to their environment through an interplay of assimilation and accommodation. ${ }^{3,4}$

The cognitive development theory is described as having a constructivist view, i.e., people construct knowledge, skills and understanding of the world using their existing knowledge to interpret new experiences. ${ }^{6}$ According to Piaget, a 'scheme' is the essential building block of cognition. It is an organized pattern of physical action and mental thought. ${ }^{3}$ An extensive interaction of each individual with their environment is essential for cognitive development to occur. The processes guiding these interactions include assimilation and accommodation: 'assimilation' being the process of bringing new information into existing schemes, and 'accommodation' being the process of modifying the existing schemes to better fit the assimilated information. ${ }^{7}$

Children tend to be naturally curious. They constantly explore and probe their environment, challenging the existing schemes and reflecting on making sense of their encounters. ${ }^{8}$ Likewise, in the dental environment, actively engaging the child will aid in their cognitive development and paediatric dentists can play a key role in shaping positive dental behaviour. The objective of the article was to prepare an outline integrating Jean Piaget's theory of cognitive development with the contemporary behaviour management techniques to enable a dentist to provide a child patient with a positive dental experience. The purpose was to review Piaget's principles on children's intellectual development and approximate them to the various studies done on behaviour management techniques thereby making chair side dentistry a more interesting and enjoyable experience for the child and less taxing for the dentist.

\section{METHODS}

For this review, various guidelines developed by societies including the American Academy of Paediatric Dentistry, the European Archives of Paediatric Dentistry were considered. Also, comparative clinical trials and randomized control trials observing the differences in various behaviour management techniques for children through infancy to eighteen years of age and approximating it to Piaget's stages of development were reviewed.

A thorough search was conducted to find the relevant articles on various search engines using the keywords: Jean Piaget, cognitive development theory, and the various behaviour management techniques including tell-show-do, distraction, communication, parenteral presence/ absence, etc. till June 2020 for published work in English. The collected material was carefully studied, comparative clinical trials and randomized control trials conducted in India were primarily selected and an outline was developed corresponding to the aims and objectives of this paper.

\section{RESULTS}

The following 4 tables summarize the outline of cognitive contemporary behaviour management according to each of Piaget's stages of cognitive development:

Table 1: Stage 1 - Sensorimotor Period (0-2 years)

Table 2: Stage II - Preoperational Period (2-7 years)

Table 3: Stage III - Concrete Operations (7-11 years)

Table 4: Stage IV - Formal Operations (12+ years)

\section{Stage 1: Sensorimotor Period [Table. 1]}

Sensorimotor period is the first stage of cognitive development from birth to two years of age. During this period, infants primarily engage in sensorimotor thoughts i.e., thoughts based on sensory input and physical or motor actions. The child at this stage is only capable of direct action on the world and is unable to form symbols. Six substages were proposed by Piaget describing the emergence of representational thought through infancy. ${ }^{3}$ The main limitations of the sensorimotor thought period are that the infant lacks symbolic thought and object permanence. However, they develop it later as the stage progresses. ${ }^{3}$ Infants in this stage are also completely egocentric and see themselves as the primary cause of all activity. They are 
therefore unable to understand another person's perspective. 3,9

\section{Effective Behaviour Management Modality}

Children up to two years of age are considered to lack the ability to cooperate due to their limited cognitive development. ${ }^{10}$ Hence, general anaesthesia or delaying of elective treatment is preferred. General anaesthesia or restraint may be performed for emergency treatment.11,12 After eighteen months of age, communication, distraction and tell-show-do may be tried as the child begins to show some evidence of symbolic behaviour. However, the success rates of these behaviour management strategies are not good as the child's language and cognitive skills are yet to develop. [Table. 1]

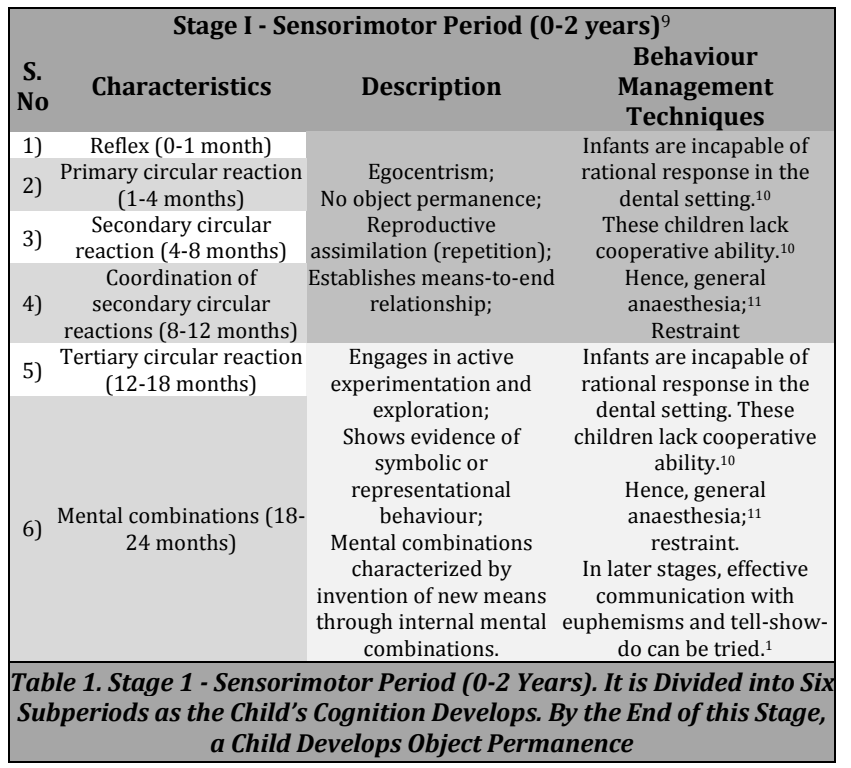

\section{Stage 2: Preoperational Thought Period [Table. 2]:}

The second stage, the preoperational thought period ranges from two to seven years. It is also referred to as the preconceptual or intuitive thought period as the child is only capable of forming a single concept of an object. It features the flourishing use of symbols in language, art and play (symbolic play, fantasy play, make-believe play) as well as mental representations. ${ }^{8}$ However, intuitive thought is based on the personal experiences of the child and not on any formal system or rules thereby leading to egocentrism, animism and artificialism. Schemes for a child in this stage are irreversible making them focus only on static endpoints thereby causing them to fail at performing tasks involving centration or conservation. ${ }^{3,7}$

These limitations and achievements have been made use of in dentistry in the form of various behaviour management techniques including distraction, tell show do, tell play do, mobile dental apps, etc. In a cross-sectional study done by Sharath Asokan et al. in 2014 to check the relevance of Piaget's cognitive principles among 200 children in the preoperational thought period, the principles of egocentrism, and lack of conservation and reversibility were found to be valid. Children tend to think symbolically about objects and base their reasoning on appearances than logic. ${ }^{7}$ Hence, using tell-show-do involving a child's visual, auditory and tactile senses invokes their symbolic thinking as observed in a retrospective study by Sharma et al. ${ }^{12}$ Tell-play-do and smartphone dental apps take advantage of this symbolic play thereby reducing anxiety and fear and improving chair side behaviour in subsequent appointments as studied by Radhakrishna et al. in 2019 and Prashanth et al. in 2017.13,14

Egocentrism in the preoperational period was proved by Piaget using the classical three mountain experiment. To take advantage of a child's egocentrism in the dental clinic, effective communication with the correct use of euphemisms as well as rewarding the child by praising them in front of their parents or peers is effective in developing a positive attitude. Allowing them to play an active role in the treatment process by asking them to perform seemingly important activities such as holding the suction tip or temporarily pausing the treatment when they raise their hand makes them feel involved and improves their chair side behaviour. $4,15,16$

\begin{tabular}{|c|c|c|c|}
\hline $\begin{array}{l}\text { S. } \\
\text { No }\end{array}$ & Characteristics & Description & $\begin{array}{c}\text { Behaviour Management } \\
\text { Techniques }\end{array}$ \\
\hline 1) & $\begin{array}{l}\text { Symbols in } \\
\text { language }\end{array}$ & $\begin{array}{l}\text { Construction of their own } \\
\text { inventive versions of } \\
\text { words and phrases; }{ }^{7} \\
\text { Echolalia (repeating of } \\
\text { words, syllables and } \\
\text { sounds) \& Onomatopoeia } \\
\text { (words that sound like } \\
\text { noises); egocentric } \\
\text { speech }\end{array}$ & $\begin{array}{l}\text { Tell-show-do }{ }^{12} \text { with the correct } \\
\text { use of euphemisms fit to child's } \\
\text { vocabulary (by } 2 \text { years - } 250 \\
\text { words; by } 5 \text { years - } 2000 \text { words) } \\
\text { Eg: slow piece handpiece may be } \\
\text { called 'uncle bumpy' as the } \\
\text { vibrations produced feel like } \\
\text { bumps to the child.; Pre-visit } \\
\text { imagery'. }\end{array}$ \\
\hline 2) & $\begin{array}{l}\text { Symbols in } \\
\text { artwork and play }\end{array}$ & $\begin{array}{c}\text { Symbolic play (use one } \\
\text { object to stand for } \\
\text { another); } \\
\text { Fantasy play (pretend to } \\
\text { be something they are } \\
\text { not); } \\
\text { Make-believe play (use } \\
\text { toys and props to carry } \\
\text { out some procedure) }\end{array}$ & $\begin{array}{c}\text { Tell-play-do; }{ }^{13} \\
\text { Pre and post-appointment games } \\
\text { involving the child pretending to } \\
\text { be a dentist with a toy dental kit } \\
\text { helping in reduction of anxiety } \\
\text { (pre-visit), reinforcing oral } \\
\text { hygiene instructions (post-visit); }{ }^{14} \\
\text { Mobile dental app; }{ }^{13}\end{array}$ \\
\hline 3) & Egocentrism & $\begin{array}{l}\text { Young child's inability to } \\
\text { take another person's } \\
\text { perspective }\end{array}$ & $\begin{array}{c}\text { Effective communication making } \\
\text { the child feel important by } \\
\text { complementing their } \\
\text { accomplishments and } \\
\text { possessions; }{ }^{15,16} \\
\text { A child is permitted to have an } \\
\text { active part in the treatment e.g.: } \\
\text { manipulate the saliva ejector or } \\
\text { hand gestures for a break in } \\
\text { between treatment (Enhancing } \\
\text { control); }{ }^{15} \\
\text { Ask-tell-ask; } \\
\text { Problem ownership. }{ }^{17}\end{array}$ \\
\hline 4) & Animism & $\begin{array}{l}\text { The idea that inanimate } \\
\text { objects have conscious } \\
\text { life and feelings }\end{array}$ & $\begin{array}{l}\text { Instruments and materials may be } \\
\text { given names with personalities. } \\
\text { Eg: suction tip be named Mr. } \\
\text { Slurpy that is always thirsty and } \\
\text { drinks away the water. }\end{array}$ \\
\hline 5) & Artificialism & $\begin{array}{l}\text { Notion that natural } \\
\text { events or objects are } \\
\text { under the control of } \\
\text { people or superhuman } \\
\text { agents }\end{array}$ & $\begin{array}{l}\text { Magic tricks; } \\
\text { Rewarding with gifts believed to } \\
\text { have magical properties. }\end{array}$ \\
\hline 6) & $\begin{array}{l}\text { Conservations; } \\
\text { Centration }\end{array}$ & $\begin{array}{l}\text { Concept that certain basic } \\
\text { properties of an object } \\
\text { remain the same even if } \\
\text { its physical appearance } \\
\text { changes; } \\
\text { Child's habit of attending } \\
\text { to one salient aspect of a } \\
\text { problem neglecting } \\
\text { others }\end{array}$ & $\begin{array}{l}\text { Distraction; }{ }^{15} \\
\text { Use of audio-visual aids, virtual } \\
\text { reality, }{ }^{18} \text { and } 3 \mathrm{D} \text { glasses; }{ }^{19} \\
\text { Aroma, }{ }^{20} \text { and music therapy for } \\
\text { relaxation and distraction; } \\
\text { Use of injection sleeves. }{ }^{21}\end{array}$ \\
\hline 7) & $\begin{array}{l}\text { Socialization of } \\
\text { behaviour }\end{array}$ & $\begin{array}{l}\text { As a result of social } \\
\text { activity with peers }\end{array}$ & $\begin{array}{c}\text { Establish dentist as authority } \\
\text { figure to be obeyed; Voice control;1 } \\
\text { Direct observation;12 } \\
\text { Reinforcements (E.g.: notice board } \\
\text { with photographs of 'good' } \\
\text { children); }{ }^{22} \\
\text { Parental presence/absence. } 1,23 \\
\end{array}$ \\
\hline \multicolumn{4}{|c|}{$\begin{array}{c}\text { Table 2. Stage } 2 \text { - Preoperational Period (2-7 Years) Child at this Stage } \\
\text { is Capable of Forming Only a Single Concept of an Object }\end{array}$} \\
\hline
\end{tabular}


In preconceptual and intuitive stages, children also attribute life to inanimate objects (animism) and also believe in magic or artificialism. ${ }^{3}$ Hence, attributing life-like properties to dental inanimate objects such as suction tip, or airotor, and micromotor can be done by giving them names, feelings, and physical associations similar to those of humans make their introduction to the child and its use in the oral cavity an easy process. ${ }^{4}$

Lack of conservation and reversibility was tested using the classical beaker experiment by Piaget. ${ }^{9}$ Distraction using audio-visual aids such as video games, virtual reality headsets and 3D glasses take advantage of these characteristics. $15,18,19$ Creating a relaxing environment while making a child focus on single specific properties of objects such as calming sounds, or aroma, or a fish aquarium in the clinic works on the principle of centration. This can be used to distract and manage their chair side behaviour. ${ }^{15,20}$

The preoperational period is also associated with the socialization of behaviour. ${ }^{24}$ Providing reinforcements as well as managing parental presence or absence in the operatory serves as effective tools for controlling the behaviour of uncooperative children by gaining their cooperation and further aiding in the provision of quality dental treatments. ${ }^{22,23,25}$ [Table. 2]

Stage 3: Concrete Operations Period [Table. 3] The third stage of Piaget's cognitive development theory is the concrete operational thought period ranging from seven to eleven years of age. ${ }^{26}$ Concrete operational thought is associated with the ability to think about two or more dimensions of a problem (decentration of thought), reversible operations, and dynamic transformations. ${ }^{3}$ Children reaching this stage are capable of logical thought, reversibility of schemes, and solving conservation problems due to decentration or the ability to consider more than one aspect of a situation. However, the logic remains limited to concrete and tangible materials and experiences. ${ }^{3,27}$

Since children at this stage are capable of classification, seriation, reversibility, transitive inferences and mental representations, the behaviour management techniques employed by the paediatric dentist should take advantage of these abilities to reduce their anxiety associated with dental procedures thereby improving behavioural outcomes. ${ }^{2,28}$ Relaxation techniques including training exercises such as bubble breath exercises have been proven to effectively reduce anxiety during buccal infiltration injections by Sridhar et al. (2019).29 Other relaxation techniques including Jacobson's progressive relaxation learning and computerassisted relaxation learning are also effective in reducing dental anxiety thereby improving chair side behaviour, attitudes and quality of treatment provided. ${ }^{28}$ Systematic desensitization or exposure therapy initially described by Wolpe is based on relaxation and encourages children to discuss their status of anxiety and fear in order to construct a hierarchy of their most feared dental situations and to gradually expose them to these situations from the least to most anxiety producing. ${ }^{25,30,31}$

Guided imagery has also been utilized successfully by Peretz et al. (2000) to give local anaesthesia to children as helping in reducing fear from the syringe and gaining better compliance from the child. ${ }^{32,28}$ Teach back technique for children in concrete operations has been observed to be beneficial by Yen PH et al. (2019) for reinforcing patient education, improved follow-ups, and overall health outcomes. ${ }^{33,34}$

Distraction methods have been studied as effective in managing children in the concrete operations stage including virtual reality, three dimensional (3D) videos, and other audio-visual aids by various authors and researchers. ${ }^{18,28,31}$ Mobile dental apps such as 'Little Lovely Dentist' (Leaf cottage software and Shanghai Edaysoft Co., Ltd.) help in engaging the child during their initial treatment and reduce anticipatory anxiety working on the principles of distraction and motivation. ${ }^{35}$ The above-mentioned contemporary behaviour management techniques take advantage of the various limitations and achievements of the concrete operations thought period to improve attitudes and compliance of children during dental treatment. [Table. 3]

\begin{tabular}{|c|c|c|c|}
\hline \multicolumn{4}{|c|}{ Stage III - Concrete Operations (7-11 years) } \\
\hline $\begin{array}{l}\text { S. } \\
\text { No }\end{array}$ & Characteristics & Description & $\begin{array}{r}\text { Behaviou } \\
\text { Te }\end{array}$ \\
\hline 1) & $\begin{array}{c}\text { Classification; } \\
\text { Ability to decenter }\end{array}$ & $\begin{array}{r}\text { Fact } \\
\text { classif } \\
\text { and }\end{array}$ & $\begin{array}{r}\text { Relax } \\
\text { (Jacobson } \\
\text { relaxation }\end{array}$ \\
\hline 2) & Seriation & Ability to & $\begin{array}{r}\text { relax: } \\
\text { Systemat }\end{array}$ \\
\hline 3) & Rever & & \\
\hline 4) & $\mathrm{T}_{\mathrm{r}}$ & $\begin{array}{r}\operatorname{Pr} \\
\text { infer } \\
\text { relat }\end{array}$ & $\begin{array}{r}\text { Parental prese } \\
\text { Teach } \\
\text { Audio-visual ai }\end{array}$ \\
\hline 5) & $\begin{array}{c}\text { Mental } \\
\text { representation }\end{array}$ & pacity of internalizations & $\begin{array}{c}\text { and video games and mobile } \\
\text { dental apps for distraction and } \\
\text { motivation; }{ }^{35} \\
\text { Guided imagery. }\end{array}$ \\
\hline \multicolumn{4}{|c|}{$\begin{array}{l}\text { Table 3. Stage } 3 \text { - Concrete Operations Period (7-11 Years). It is } \\
\text { Associated with the Child's Ability to Think about More Than a Single } \\
\text { Dimension of a Problem, as Well as Understand Transformations }\end{array}$} \\
\hline
\end{tabular}

Stage 4: Formal Operations Period [Table. 4] The formal operational thought period was described as the last stage of cognitive development by Jean Piaget from ages twelve years and above.26,27 Piaget believed that at adolescence an individual reaches their fullest potential and develops formal operational thought characterized by five higher-level cognitive thinking abilities including hypothetico-deductive reasoning, extending logical thinking to abstract concepts, considering all possible logical combinations, separating reality and possibilities, and reflecting on one's thoughts. ${ }^{3,8}$ Hypothetico-deductive reasoning is the ability to use deductive reasoning to manipulate several variables systematically to reach correct conclusions of complex problems. ${ }^{3}$ The major limitation of this stage is adolescent egocentrism presented in the form of imaginary audience and personal fable. $5,9,27$

Contemporary behaviour management techniques that gain from logical thought include biofeedback i.e., a mindbody technique assisting the patient to attain self-regulation and control thereby encouraging improved behaviour in the dental setting. ${ }^{38,28}$ Systematic desensitization or exposure therapy described by Wolpe is a valuable tool in managing dental anxiety and improving chair side behaviour as well.25,39,28,30

Cognitive behaviour therapy involving learning to effectively change negative and distorted thoughts and actions into more positive ones helps alleviate anxiety and promote a better dental experience. ${ }^{38}$ 
Guided imagery, teach-back and relaxation techniques are also useful in managing the behaviour of children in their formal operational thought period. $33,32,28,34$ Gaining advantage from adolescent egocentrism, teenagers can be motivated using aesthetic models for various treatments including orthodontic corrections. ${ }^{40,41}$ Providing positive reinforcement along with problem ownership and good communication skills can improve behaviour and help in providing quality dental treatment. ${ }^{1,28,24}$ [Table. 4]

\begin{tabular}{|c|c|c|c|}
\hline \multicolumn{4}{|c|}{ Stage IV - Formal Operations (12+ Years) } \\
\hline S. No. & $\begin{array}{c}\text { Characteris } \\
\text { tics }\end{array}$ & Description & $\begin{array}{l}\text { Behaviour } \\
\text { Management } \\
\text { Techniques }\end{array}$ \\
\hline 1) & $\begin{array}{l}\text { Hypothetico- } \\
\text { deductive } \\
\text { reasoning }\end{array}$ & $\begin{array}{l}\text { Reasoning from general } \\
\text { principles to particular } \\
\text { conclusions }\end{array}$ & \multirow{4}{*}{$\begin{array}{l}\text { Biofeedback; } \\
\text { Systematic desensitization } \\
\text { or exposure therapy; }{ }^{39} \\
\text { Cognitive therapy; }{ }^{28} \\
\text { Iatrosedative technique; }{ }^{43} \\
\text { Guided imagery; }{ }^{32} \\
\text { Computer assisted } \\
\text { relaxation learning; }{ }^{28} \\
\text { Memory reconstruction; }{ }^{28} \\
\text { Teach back. }{ }^{34}\end{array}$} \\
\hline 2) & $\begin{array}{l}\text { Abstract } \\
\text { thought }\end{array}$ & $\begin{array}{l}\text { Thoughts about tangible things } \\
\text { such as concepts or ideas }\end{array}$ & \\
\hline 3) & $\begin{array}{l}\text { Combination } \\
\text { logic }\end{array}$ & $\begin{array}{l}\text { Ability to generate and } \\
\text { systematically consider all } \\
\text { possible combinations of a set of } \\
\text { elements. }\end{array}$ & \\
\hline 4) & $\begin{array}{l}\text { Reflective } \\
\text { thinking }\end{array}$ & $\begin{array}{l}\text { Ability to think about their own } \\
\text { thoughts. }\end{array}$ & \\
\hline 5) & $\begin{array}{l}\text { Adolescent } \\
\text { egocentrism }\end{array}$ & $\begin{array}{l}\text { Imaginary audience; personal } \\
\text { fable. }{ }^{42}\end{array}$ & $\begin{array}{c}\text { Motivation using } \\
\text { aesthetics; }{ }^{40,41} \\
\text { Positive reinforcement; }{ }^{24} \\
\end{array}$ \\
\hline \multicolumn{4}{|c|}{$\begin{array}{c}\text { Table 4. Stage } 4 \text { - Formal Operations Period (12+ Years). An Individual } \\
\text { in this Stage Reaches Their Fullest Level of Cognition }\end{array}$} \\
\hline
\end{tabular}

It should be noted that communication, positive reinforcement, distraction, music therapy and aromatherapy have been applied to all ages and stages effectively.1,2,20,44 Aversive techniques, sedation and general anaesthesia may also be used for any group after careful consideration of the individual child's behaviour, parental consent, and the clinician's comfort. ${ }^{10,11,45,46}$

\section{CONCLUSIONS}

Behaviour management techniques when applied appropriately to the correct age and stage of intellectual development for a child can lead to successful treatment with a positive dental experience. This outline provides a template for paediatric dentists enabling them to successfully provide better behavioural treatment outcomes clinically.

While literature exists on various dental behaviour management techniques as well as on different behaviours exhibited by children, it can still be puzzling to dental practitioners especially beginners and dentists outside the field of paediatrics as to which behavioural technique to be applied. This review aims to serve as a template for dental practitioners to decide the age-appropriate technique for behaviour management of children. Corresponding the cognitive development of a child to their age can make the tedious task of managing them effectively in the dental environment a little easier. This may in the long run help to alleviate a child's dental phobias making them better paediatric and adult patients in the near future.

Financial or other competing interests: None.

Disclosure forms provided by the authors are available with the full text of this article at jemds.com.

\section{REFERENCES}

[1] Behavior guidance for the pediatric dental patient. Pediatr Dent 2018;40(6):254-67.

[2] Roberts JF, Curzon MEJ, Koch G, et al. Review: behaviour management techniques in paediatric dentistry. Eur Arch Paediatr Dent 2010;11(4):166-74.

[3] Cook JL, Cook G. Child development: principles and perspectives. $2^{\text {nd }}$ edn. Pearson 2009.

[4] Christen AG. Piagetian psychology: some principles as helpful in treating the child dental patient. ASDC J Dent Child 1977;44(6):448-52.

[5] Johnson AP. Cognitive Development: JEAN Piaget. Educ Psychol Theor Learn Hum Dev 2014;(2007):1-11.

[6] Müller U, Sokol B, Overton WF. Refraining a constructivist model of the development of mental representation: the role of higher-order operations. Dev Rev 1998;18(2):155-201.

[7] Heo J, Han S, Koch C, et al. Piaget's egocentrism and language learning: language egocentrism (LE) and language differentiation (LD). J Lang Teach Res 2011;2(4):733-9.

[8] Piaget J, Cook M. The origins of intelligence in children. J Consult Psychol 1953;17(6):467-7.

[9] Berk LE. Development through the lifespan, $4^{\text {th }}$ edn. Pearson 2007.

[10] Dean JA, Jones JE, Walker Vinson LQA. McDonald and Avery's dentistry for the child and adolescent. $10^{\text {th }}$ edn. Elsevier 2015.

[11] Wright GZ, Kupietzky A. Behavior management in dentistry for children. $2^{\text {nd }}$ edn. John Wiley \& Sons, Inc. 2014:1-248.

[12] Tyagi R, Sharma A. Behavior assessment of children in dental settings: a retrospective study. Int J Clin Pediatr Dent 2011;4(1):35-9.

[13] Radhakrishna S, Srinivasan I, Setty JV, et al. Comparison of three behavior modification techniques for management of anxious children aged 4-8 year. J Dent Anesth Pain Med 2019;19(1):29-36.

[14] Vishwakarma AP, Bondarde PA, Patil SB, et al. Effectiveness of two different behavioral modification techniques among 5-7-year-old children: a randomized controlled trial. J Indian Soc Pedod Prev Dent 2017;2(35):143-9.

[15] Damle SG. Child labour: A bitter truth. J Indian Soc Pedod Prev Dent 2006;24(4):172.

[16] Delitala G. Incorporating Piaget's theories into behavior management techniques for the child dental patient. Gen Dent 2000;48(1):74-6.

[17] Fayle SA, Tahmassebi JF. Paediatric dentistry in the new millennium: 2. Behaviour management--helping children to accept dentistry. Dent Update 2003;30(6):294-8.

[18] Shetty V, Suresh LR, Hegde AM. Effect of virtual reality distraction on pain and anxiety during dental treatment in 5 to 8 year old children. J Clin Pediatr Dent 2019;2(43):97-102.

[19] Navit S, Johri N, Khan SA, et al. Effectiveness and comparison of various audio distraction aids in management of anxious dental paediatric patients. J Clin Diagnostic Res 2015;9(12):ZC05-9.

[20] Arslan I, Aydinoglu S, Karan NB. Can lavender oil inhalation help to overcome dental anxiety and pain in 
children? A randomized clinical trial. Eur J Pediatr 2020;179(6):985-92.

[21] Melwani AM, Srinivasan I, Setty JV, et al. A clinical comparative study between conventional and camouflaged syringes to evaluate behavior and anxiety in 6-11-year-old children during local anesthesia administration-a novel approach. J Dent Anesth Pain Med 2018;18(1):35-40.

[22] Rank RCIC, Vilela JER, Rank MS, et al. Effect of awards after dental care in children's motivation. Eur Arch Paediatr Dent 2019;20(2):85-93.

[23] Ahuja S, Gandhi K, Malhotra R, et al. Assessment of the effect of parental presence in dental operatory on the behavior of children aged 4-7 years. J Indian Soc Pedod Prev Dent 2018;36(2):167-72.

[24] Marshman Z, Morgan A, Porritt J, et al. Protocol for a feasibility study of a self-help cognitive behavioural therapy resource for the reduction of dental anxiety in young people. Pilot Feasibility Studies 2016;2:13.

[25] Hamzah HS, Gao X, Yiu CKY, et al. Managing dental fear and anxiety in pediatric patients: a qualitative study from the public's perspective. Pediatr Dent 2014;36(1):29-33.

[26] Piaget-Cognitive-Development-in-Children.pdf.

[27] Sandwell J. Piaget's Stage Theory of Development. Dep Psychol Univ Alberta 2004.

[28] Appukuttan DP. Strategies to manage patients with dental anxiety and dental phobia: literature review. Clin Cosmet Investig Dent 2016;8:35-50.

[29] Sridhar S, Suprabha BS, Shenoy R, et al. Effect of a relaxation training exercise on behaviour, anxiety, and pain during buccal infiltration anaesthesia in children: randomized clinical trial. Int J Paediatr Dent 2019;29(5):596-602.

[30] Wolpe J. Reciprocal inhibition as the main basis of psychotherapeutic effects. Arch Neurol Psychiatry 1954;72(2):205-26.

[31] Taylor GD, Campbell C. A clinical guide to needle desensitization for the paediatric patient. Dent Update 2015;42(4):373-82.

[32] Peretz B, Bimstein E. The use of imagery suggestions during administration of local anesthetic in pediatric dental patients. J Dent Child 2000;67(4):263-31.

[33] Yen PH, Leasure AR. Use and effectiveness of the teachback method in patient education and health outcomes. Fed Pract 2019;36(6):284-9.
[34] Goleman J. Cultural factors affecting behavior guidance and family compliance. Pediatr Dent 2014;36(2):121-7.

[35] Elicherla SR, Bandi S, Nuvvula S, et al. Comparative evaluation of the effectiveness of a mobile app (Little Lovely Dentist) and the tell-show-do technique in the management of dental anxiety and fear: a randomized controlled trial. J Dent Anesth Pain Med 2019;19(6):36978.

[36] Vasiliki B, Konstantinos A, Vassilis K, et al. The effect of parental presence on the child's perception and cooperation during dental treatment. Eur Arch Paediatr Dent 2016;17(5):381-6.

[37] Papadopoulos L, Pentzou AE, Louloudiadis K, et al. Design and evaluation of a simulation for pediatric dentistry in virtual worlds. J Med Internet Res 2013;15(11):e240.

[38] Robertson M, Araujo M, Innes N. Anxiety and fear management in paediatric dentistry using distraction techniques. Evid Based Dent 2019;20(2):50-1.

[39] Barenie JT, Ripa LW. The use of behavior modification techniques to successfully manage the child dental patient. J Am Dent Assoc 1977;94(2):329-34.

[40] Walker K, Jackson R. The health belief model and determinants of oral hygiene practices and beliefs in preteen children: a pilot study. Pediatr Dent 2015;37(1):40-5.

[41] Hall-Scullin E, Goldthorpe J, Milsom K, et al. A qualitative study of the views of adolescents on their caries risk and prevention behaviours. BMC Oral Health 2015;15:141.

[42] Schwartz PD, Maynard AM, Uzelac SM. Adolescent egocentrism: a contemporary view. Adolescence 2008;43(171):441-8.

[43] Friedman N, Wood GJ. An evaluation of the iatrosedative process for treating dental fear. Compend Contin Educ Dent 1998;19(4):434-6.

[44] Packyanathan JS, Lakshmanan R, Jayashri P. Effect of music therapy on anxiety levels on patient undergoing dental extractions. J Family Med Prim Care 2019;8(12):3854-60.

[45] Marshman Z, Timms L. What is the impact on families of children having dental treatment under general anaesthetic? Evid Based Dent 2019;20(2):48-9.

[46] Knapp R, Marshman Z, Rodd H. Treatment of dental caries under general anaesthetic in children. BDJ Team 2017;4:17116. 